\title{
RANCANG BANGUN SISTEM INFORMASI PERINTAH KERJA OVERTIME PEGAWAI BERBASIS WEB PADA PT PLN BATAM
}

\section{Tukino}

Universitas Putera Batam, Jl. R. Soeprapto Mukakuning, Batam 29434, Indonesia

\section{INFORMASI ARTIKEL \\ Diterima Redaksi: 5 Agustus 2018 \\ Diterbitkan Online: 30 September 2018}

\begin{tabular}{l} 
KATA KUNCI \\
\hline $\begin{array}{l}\text { Sistem Informasi } \\
\text { Overtime }\end{array}$
\end{tabular}

\section{KORESPONDENSI}

E-mail: mas.kino@gmail.com

\begin{abstract}
A B S T R A C T
Perancangan sistem informasi ini didasari belum adanya penggunaan sistem informasi perintah kerja lembur yang berbasis web di PT PLN Batam (b'right). Dimana sistem informasi berbasis web ini digunakan oleh staff dan manager perusahaan untuk membantu proses penyelesaian pekerjaan administrasi kerja lembur salah satunya berupa Surat Perintah Kerja Lembur (SPKL) sehingga laporan upah lembur tidak menumpuk dan segera dapat dibayar namun tidak menyalahi prosedur kerja lembur yang ada di PT PLN Batam (b'right). Selama ini penyelesaian administrasi perintah kerja lembur selalu lambat ditambah lagi dengan perkiraan jumlah karyawan di PT PLN Batam (b'right) akan semakin bertambah setiap tahunnya akan semakin menimbulkan masalah dalam proses perintah kerja lembur di PT PLN Batam (b'right). Metode perancangan yang digunakan dalam penelitian ini adalah menggunakan Unified Modelling Language (UML) versi 2.3 dengan System Development Life Cycle (SDLC) mengunakan model Waterfall. Sistem ini akan menghasilkan sistem informasi perintah kerja lembur yang cepat yang akan membuat kinerja Manager dan staff semakin efektif dan efisien karena sistem informasi ini berbasis web yang mudah di akses.
\end{abstract}

\section{Latar Belakang}

PT Pelayanan Listrik Nasional Batam atau PT PLN Batam (b'right) yang berkantor pusat di Jalan Engku Putri No. 3 Batam Center, merupakan perusahaan dengan wilayah operasional saat ini adalah Pulau Batam, Rempang dan Galang serta tidak menutup kemungkinan akan melakukan ekspansi usaha ke seluruh wilayah Indonesia, hal ini tertuang dalam visi PT PLN Batam yaitu menjadi perusahaan penyedia energi utama di Indonesia. Sebagai perusahaan utilitas penyedia layanan jasa kelistrikan, PT PLN Batam selalu dituntut untuk melayani kebutuhan listrik kepada masyarakat dengan sebaik-baiknya hal ini berdampak terhadap pegawai yang selalu dituntut untuk berkinerja tinggi sehingga mengakibatkan adanya pegawai bekerja melebihi dari waktu kerja normal.

PT PLN Batam memiliki jumlah pegawai sekitar 343 pegawai dan setiap tahunnya akan terus berkembang. Walaupun peraturan lembur dan prosedur lembur di PT PLN Batam telah dibuat sebaik mungkin tanpa ditunjang dengan sebuah sistem informasi maka terasa sulit bagi user menjalankan prosedur dan peraturan tersebut. Selama ini para atasan sangat keberatan 
membuatkan surat perintah kerja lembur (SPKL) sebelum pelaksanaan kerja lembur dimulai dengan alasan sudah terlalu sibuknya pekerjaan rutinitas sehari-hari. Masalah yang timbul dikemudian hari adalah menumpuknya tagihan pembayaran upah lembur yang disampaikan ke bagian payroll atau departemen SDM dan paling cepat disampaikan sebulan sekali bahkan bisa menumpuk sampai 3 bulan padahal standard yang diiginkan paling lambat 1 minggu, hal ini berdampak terhadap cash flow perusahaan sehingga semakin sulitnya pembayaran upah lembur pegawai dilakukan.

Sesuai dengan peraturan lembur di PT PLN Batam nomor: 0005.K/DIR/2016, bahwa pelaksanaan pekerjaan yang dilemburkan harus kategori pekerjaan penting atau mendesak, hal ini menjadi alasan lain sulitnya para atasan mencari alasan pekerjaan yang berkategori mendesak dan penting, sehingga SPKL sulit dibuat. Katagori pekerjaan penting atau mendesak adalah pekerjaan yang apabila tidak diselesaikan dapat menimbulkan kerugian atau kehilangan pendapatan atau menggangu kelancaran produksi atau menimbulkan kosekuensi yang menghambat kinerja perusahaan serta yang dapat membahayakan kesehatan atau keselamatan manusia.

Pegawai yang berhak atas upah lembur paling sedikit telah berkerja lembur satu jam penuh dan hanya diberikan kepada pegawai dengan jenjang jabatan fungsional maupun Struktural pada grade basic dan grade specific. Pegawai fungsional grade specific dan pegawai struktural grade basic dan specific hanya berhak atau upah lembur yang dilaksanakan pada hari libur saja, sedangkan pegawai fungsional dengan grade basic mendapat hak upah lembur atas pekerjaan lembur yang dilakukan pada hari kerja maupun hari libur.

\section{Kajian Literatur}

\section{A. Pengertian Sistem}

Menurut [5] Sistem adalah kumpulan dari elemen-elemen yang berinteraksi untuk mencapai suatu tujuan tertentu. Elemen Sistem adalah suatu sistem terdiri dari sejumlah elemen yang saling berinteraksi, yang artinya saling kerjasama membentuk satu kesatuan. Sedangkan menurut [6] Sistem adalah sekumpulan elemen yang saling terkait atau terpadu yang dimaksudkan untuk mencapai suatu tujuan.

Untuk menghasilkan suatu sistem yang baik dibutuhkan suatu pengkajian lebih mendalam terhadap sistem tersebut. Suatu sistem bersifat dinamis dan tidak statis, hal ini mengindikasikan bahwa suatu sistem akan selalu berubah dari bentuk yang paling sederhana menuju bentuk yang sempurna. Namun. Untuk mencapai kesempurnaan sistem sangatlah sulit, hal ini karena sistem merupakan bagian-bagian, atau komponen-komponen yang saling melengkapi dan berinteraksi satu sama lainnya untuk mencapai tujuannya [7].

Dari definisi sistem diatas maka penyusun menyimpulkan bahwa sistem merupakan suatu jaringan kerja dari prosedur-prosedur yang saling berhubungan, berkumpul bersama-sama untuk melakukan suatu kegiatan atau menyelesaikan suatu sasaran tertentu. Arti yang lain adalah kumpulan dari elemen-elemen yang berinteraksi untuk mencapai tujuan tertentu.

\section{B. Pengertian Informasi}

Menurut [4] Informasi adalah data yang telah diolah menjadi bentuk yang lebih berarti dan berguna bagi penerimanya untuk mengambil keputusan masa kini maupun masa yang akan datang. Sedangkan menurut [6] Informasi merupakan salah satu sumber daya penting dalam manajemen modern.

Pendapat lain menurut [10] Informasi adalah data yang telah diproses sedemikian rupa sehingga meningkatkan pengetahuan seseorang yang menggunakan data tersebut. Seangkan pendapat lain menurut [11] Informasi adalah data yang telah diklasifikasi atau diolah atau diinterpretasi untuk digunakan dalam proses pengambilan keputusan.

\section{Sistem Informasi}

Menurut [2] Sistem informasi merupakan suatu kumpulan dari komponen-komponen dalam suatu perusahaan atau organisasi yang berhubungan dengan prses penciptaan dan pengaliran infomasi. Dalam hal ini, TI hanya merupakan salah satu komponen dalam perusahaan. Komponen-komponen lainnya adalah prosedur, struktur organisasi, sumber daya manusia, produk, pelanggan, rekanan dan sebagainya. Keandalan suatu sistem informasi 
dalam organisasi terletak pada keterkaitan antar komponen yang ada, sehingga dapat dihasilkan dan dialirkan suat informasi yang berguna (akurat, terpercaya, detail, cepat, relevan, dan sebagainya) untuk lemabaga yang bersangkutan.

Sedangkan menurut [3], sistem informasi merupakan sistem yang mempuyai kemampuan untuk mengumpulkan informasi dari semua sumber dan menggunakan berbagai media untuk menampilkan informasi.

Berdasarkan penjelasan di atas, maka yang dimaksud dengan sistem informasi adalah suatu sistem di dalam suatu organisasi yang merupakan kombinasi dari orang-orang, fasilitas, teknologi media, prosedur-prosedur dan pengendalian yang ditujukan untuk mendapatkan jalur informasi penting guna memproses tipe transaksi rutin tertentu yang menyediakan suatu dasar informasi untuk pengambilan keputusan yang cerdik. Sistem informasi juga merupakan sekumpulan prosedur organisasi yang pada saat dilaksanakan akan memberikan informasi bagi pengambil keputusan dan atau untuk mengendalikan organisasi.

\section{PHP}

Menurut [12] PHP atau kependekan Hypertext Preprocessor adalah salah satu bahasa pemrograman open source yang sangat cocok atau dikhususkan untuk pengembangan web dan dapat ditanamkan pada sebuah skrip HTML [12]. Sistem kerja PHP diawali dengan permintaan yang berasal dari halaman website oleh browser. Berdasarkan URL atau alamat website dalam jaringan internet, browser akan menemukan sebuah alamat dari webserver, mengidentifikasi halaman yang dikehendaki, dan menyampaikan segala informasi yang dibutuhkan oleh webserver.

\section{MySQL (My Structure Query Language)}

Menurut [13], My Structure Query Language atau MySQL adalah salah satu Database Management System (DBMS) dari sekian banyak DBMS seperti Oracle, MS SQL, Postagre SQL, dan lainnya. MySQL berfungsi untuk mengolah database menggunakan bahasa SQL. MySQL bersifat open source sehingga dapat digunakan secara gratis.

[13], MySQL merupakan salah satu database kelas dunia yang sangat cocok bila dipadukan dengan bahasa pemrograman PHP.
MySQL bekerja dengan menggunakan bahasa SQL (Structure Query Language) yang merupakan bahasa standar yang digunakan untuk manipulasi database

\section{E. Peraturan PT PLN Batam Tentang Kerja Lembur}

Pelaksanaan pekerjaan lembur di PT PLN Batam diatur sesuai keputusan Direksi nomor: 0005.K/DIR/2016 tanggal 1 Maret 2016. Pekerjaan yang dikatagorikan kedalam pekerjaan lembur adalah pekerjaan yang apabila tidak segera diselesaikan dapat menimbulkan kerugian atau kehilangan pendapatan atau mengganggu kelancaran produksi atau menimbulkan konsekuensi yang menghambat kinerja perusahaan. Pekerjaan yang apabila tidak segera dikerjakan dapat membahayakan kesehatan dan keselamatan jiwa.

Jam Kerja, waktu Istirahat kerja, waktu lembur diatur dalam pasal 77 sampai pasal 85 Undang-Undang No.13 tahun 2003 tentang Ketenagakerjaan. Di beberapa perusahaan, jam kerja,waktu istirahat dan lembur dicantumkan dalam Perjanjian Kerja Bersama (PKB).

Karyawan yang bekerja 6 hari dalam seminggu, jam kerjanya adalah 7 jam dalam 1 hari dan 40 jam dalam 1 minggu. Sedangkan untuk karyawan dengan 5 hari kerja dalam 1 minggu, kewajiban bekerja mereka 8 jam dalam 1 hari dan 40 jam dalam 1 minggu.

Jam Kerja adalah waktu untuk melakukan pekerjaan, dapat dilaksanakan siang hari dan atau malam hari. Jam Kerja bagi para pekerja di sektor swasta diatur dalam Undang-Undang No.13 tahun 2003 tentang Ketenagakerjaan, khususnya pasal 77 sampai dengan pasal 85. Pasal 77 ayat 1 , UU No.13/2003 mewajibkan setiap pengusaha untuk melaksanakan ketentuan jam kerja. Ketentuan jam kerja ini telah diatur dalam 2 sistem seperti yang telas disebutkan diatas yaitu:

1. Tujuh jam kerja dalam 1 hari atau 40 jam kerja dalam 1 minggu untuk 6 hari kerja dalam 1 minggu; atau

2. Delapan jam kerja dalam 1 hari atau 40 jam kerja dalam 1 minggu untuk 5 hari kerja dalam 1 minggu.

3. Pada kedua sistem jam kerja tersebut juga diberikan batasan jam kerja yaitu 40 (empat puluh) jam dalam 1 (satu) minggu. Apabila melebihi dari ketentuan waktu kerja tersebut, 
maka waktu kerja biasa dianggap masuk sebagai waktu kerja lembur sehingga pekerja/buruh berhak atas upah lembur.

Tahapan rancang bangun Sistem Informasi Perintah Kerja Overtime Pegawai berbasis web menggunakan metode Agile SDLC (System Development Life Cycle). Dalam perkembangannya SDLC dilengkapi oleh berbagai teknik pengembangan sistem, dalam penelitian ini digunakan teknik pengembangan sistem. Berikut ini adalah tahap-tahap metode pengembangan SDLC adalah sebagai berikut:

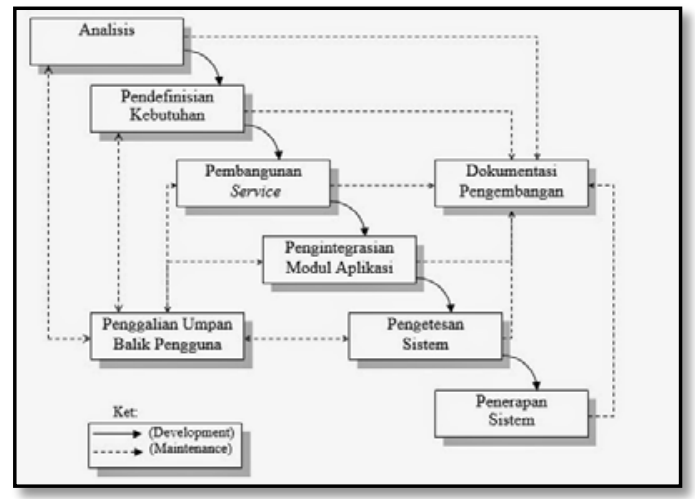

Gambar 1 Kerangka Pemikiran Model Pengembangan Sistem Adaptasi Agile SDLC Model

\section{Metodologi}

Metode pendekatan sistem yang digunakan oleh penulis adalah pendekatan berbasis objek. Terdapat beberapa alasan penulis menggunakan pendekatan berbasis objek diantaranya adalah mudah dipahami dan mudah digunakan artinya metode ini mudah dimengerti. Metode Prototyping merupakan suatu pendekatan yang paling banyak digunakan untuk pengembangan perangkat lunak. Alasan menggunakan metode Prototyping karena sifat dari aplikasi yang di kembangkan dengan cepat melalui tahapan-tahapan yang ada meliputi: Planning / Perencanaan, Design / Perancangan, Coding / Pengkodean dan Testing /Pengujian.

Setelah implementasi sistem selesai, maka selanjutnya dilakukan pengujian sistem. Pendekatan pengujian yang digunakan pada penelitian ini adalah pengujian black-box. Pengujian black-box berkaitan dengan pengujian yang dilakukan pada interface perangkat lunak. Pengujian black-box digunakan untuk memperlihatkan bahwa fungsi-fungsi perangkat lunak adalah operasional; bahwa input diterima dengan baik dan output dihasilkan dengan tepat, dan integritas informasi eksternal (seperti file data) dipelihara. Pengujian black-box berusaha menemukan kesalahan dalam kategori sebagai berikut: 1). Fungsi-fungsi yang tidak benar atau hilang; 2). Kesalahan interface; 3). Kesalahan dalam struktur data atau akses database eksternal; dan 4). Kesalahan kinerja.

\section{A. Analisa Sistem Yang Sedang Berjalan}

Sistem yang digunakan saat masih sederhana dan manual yaitu dengan menggunakan media komputer sebagai alat bantu untuk menghitung dan alat ketik biasa serta print out form SPKL sebagai bukti perintah kerja lembur. Perlu dibuat sistem yang baru agar terkomputerisasi sehingga dapat lebih efektif dan efisien.

Aliran sistem informasi perintah kerja lembur yang sedang berjalan saat di PT PLN Batam dapat terlihat yaitu seperti gambar 2 dibawah ini:

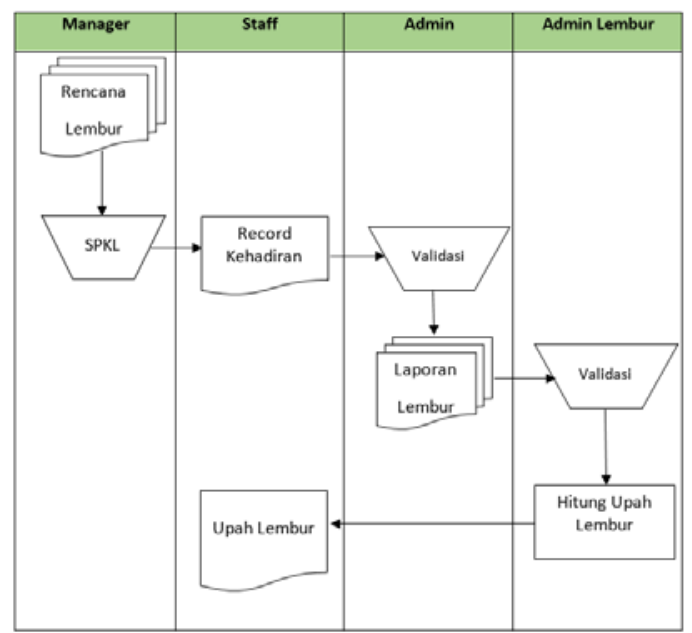

Gambar 2. Aliran Sistem Informasi Yang Sedang Berjalan

Prosedur pengelolaan lembur di PT PLN Batam diatur dengan keputusan Direksi nomor : 030.K/010/DIR/2010 sebagai berikut:

1. Atasan menerbitkan dan menandatangani Surat Perintah Kerja Lembur (SPKL).

2. Unit mengumpukan SPKL.

3. Unit membuat laporan kerja lembur. 
4. Unit menyiapkan data kehadiran dari mesin Fingerprint.

5. Atasan membuat Nota Dinas permohonan pembayaran upah lembur ke HRD.

6. HRD menyiapkan daftar pembayaran upah lembur dan melakukan entri data pembayaran dalam Aplikasi Payroll.

\section{B. Permasalahan Yang Sedang Dihadapi}

Proses pelaksanaan kerja lembur dilingkungan PT PLN Batam saat ini belum berjalan sesuai dengan prosedur kerja lembur dan peraturan kerja lembur yang telah ditetapkan perusahaan, dimana belum dilaksana secara real time perintah kerja lembur akan membuat masalah tersendiri.

Laporan kerja lembur yang dibuat berdasarkan periode tertentu, baik mingguan maupun bulanan akan menyebabkan karyawan meminta bayaran upah lembur jika ada kelebihan jam kerja yang dilihat dalam laporan monitoring kehadiran baik perminggu maupun perbulan, padahal belum tentu kelebihan atas jam kerja dalam periode tersebut akibat diperintanya kerja lembur oleh atasannya, akibat dari tidak secara real time perintah kerja lembur ini sehingga pegawai menuntut untuk dibuatkan Surat Perintah Kerja Lembur (SPKL), atasan terpaksa menandatangani SPKL tersebut malaupun atasan tersebut tidak persis ingat apakah kelebihan jam kerja tersebut akibat pernah diperintanya kerja lembut terhadap karyawan tersebut, masalah ini mejadikan integritas data lembur karyawan menjadi kurang baik.

1. Hal lain yang dirasakan pegawai terhadap adannya upah lembur yang didapatkan juga menjadikan tambahan penghasilan lain dari gaji yang diterima setiap bulan sehingga memicu pegawai berharap untuk berkerja lembur walaupun pekerjaan lembur tersebut tidak dalam katagori penting dan mendesak.

2. Masalah kerja lembur juga terjadi pada alasan dilaksanakannya kerja lembur, apakah perkerjaan lembur tersebut dalam katagori pekerjaan penting dan mendesak, jika tidak dalam katagori penting dan mendesak maka kerja lembur yang dilaksanakan tidak akan efektif.

3. Laporan yang direkap dan dikumpukan berdasarkan periode tertentu juga akan mengakibatkan terjadi kelambatan penyampain laporan kerja lembur, sehingga pembayaran upah lebur karyawan menjadi terlambat, hal ini akan mengakibatkan karyawan akan menolak untuk melaksanakan kerja lembur.

\section{Usulan Pemecahan Masalah}

Pengelolaan lembur di PT PLN Batam perlu adanya sebuah sistem yang menggunakan teknologi informasi dalam mendukung proses kerja lembur di PT PLN Batam. Usulan pemecahan masalah dapat dilihat dalam diagram alir dibawah ini:

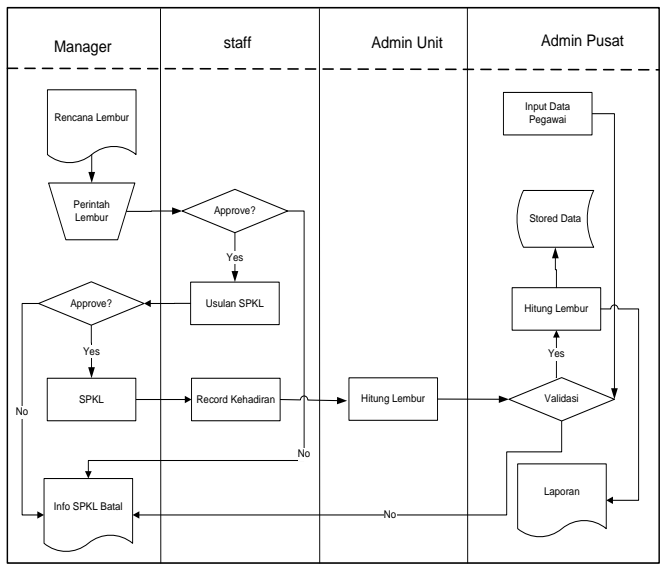

Gambar 3 Rencana Aliran Sistem Informasi Yang Di Usulkan

\section{Pembahasan}

\section{A. Aliran Sistem Informasi yang Baru}

Sistem perintah kerja lembur yang baru berbeda dengan sistem yang lama, karena sistem yang baru berjalan menggunakan sebuah aplikasi yang terkomputerisasi walaupun pada sistem lama juga mengunakan beberapa aplikasi untuk mengolah data dan membuat laporan namun masih banyak proses yang dilakukan secara menual.

Sistem informasi perintah kerja lembur yang baru akan membuat aliran data berjalan dalam sebuah jaringan internet perusahaan secara real time sehingga hal ini akan mempermudah dalam pembuatan laporan lembur dan proses perhitungan upah lembur sehingga setiap manajer akan mudah membuatkan SPKL.

Setiap manajer akan mudah membuat SPKL karena sudah dilakukan secara online dengan sebuah web, tidak lagi harus menulis dan 
menandatangan form manual diatas kertas secara perodik yang kadang dibuatnya seminggu sekali atau sebulan sekali. Alur proses pada sistem informasi perintah kerja lembur yang baru lebih singkat singkat dimana tugas Admin Unit tidak ada lagi karena semua laporan lembur langung masuk ke Admin lembur dan langsung dilakukan validasi.

Alur sistem informasi perintah kerja lembur diawali dari membuat rencana lembur atau perintah lembur yang sifatnya tiba-tiba karena ada pekerjaan urgent yang disampaikan oleh manager kepada staff, kemudian staff yang diperintahkan menyetujui kerja lembur tersebut dengan membuat usulan perintah kerja lembur melalui aplikasi Sistem Informasi Perintah Kerja Lembur dan selanjutnya dalam aplikasi tersebut manager meyetujui usulan yang disapaikan dengan menerbitkan Surat Perintah Kerja Lembur (SPKL) kemudian staff tersebut melaksanakan kerja lembur dan melakukan record kehadiran dengan mesin absensi fingerprint. Setelah surat perintah kerja lembur diterbitkan maka Admin Lembur dapat memonitor surat perintah kerja lembur melalui aplikasi sistem perintah kerja lembur tersebut kemudian admin lembur menghitung upah lembur dan membuat laporan pembayaran upah lembur untuk disetujui oleh Head of HR Administrator Department

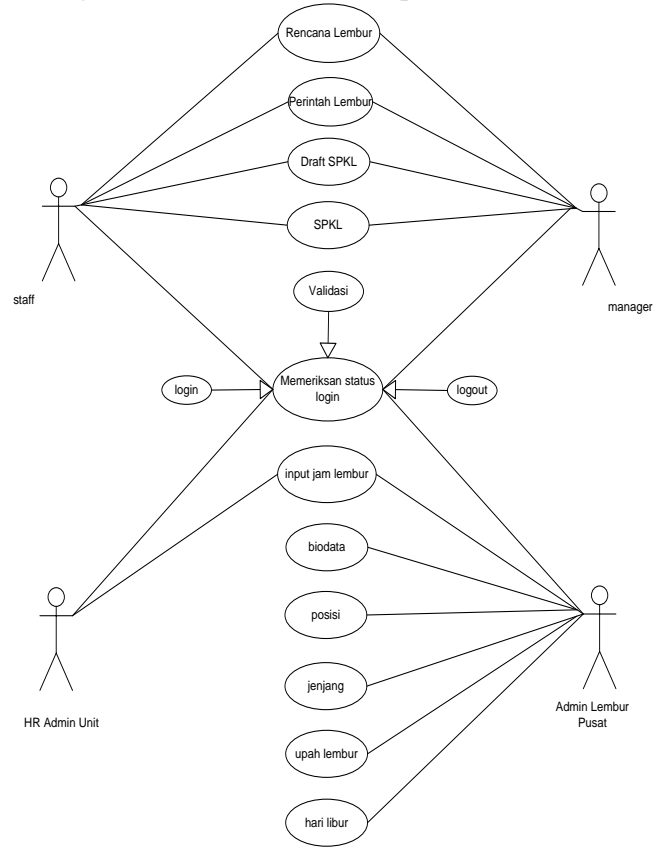

Gambar 4 Use case Informasi Perintah Lembur
Deskripsi pendefinisian actor pada sistem informasi perintah kerja lembur adalah sebagai berikut:

Tabel 1 Definisi Aktor

\begin{tabular}{|l|l|l|}
\hline No & Aktor & \multicolumn{1}{|c|}{ Deskripsi } \\
\hline 1. & Manager & $\begin{array}{l}\text { Orang yang memerintahkan } \\
\text { kerja lembur, menyetujui } \\
\text { draft Surat Perintah Kerja } \\
\text { Lembur (SPKL) dan } \\
\text { menyampaikan SPKL dan } \\
\text { mengirimkan SPKL ke Staff }\end{array}$ \\
\hline 2. & Staff & $\begin{array}{l}\text { Orang yang bertugas } \\
\text { menerima perintah kerja } \\
\text { lembur, membuat draft } \\
\text { (SPKL) dan menerima SPKL } \\
\text { dari Manager. }\end{array}$ \\
\hline 3. & $\begin{array}{l}\text { HR } \\
\text { Admin } \\
\text { Unit }\end{array}$ & $\begin{array}{l}\text { Orang yang bertugas } \\
\text { menginput realisasi jam kerja } \\
\text { lembur yang didapatkan dari } \\
\text { aplikasi fingerprint. }\end{array}$ \\
\hline 4. & $\begin{array}{l}\text { Admin } \\
\text { Lembur } \\
\text { Pusat }\end{array}$ & $\begin{array}{l}\text { Orang yang bertugas } \\
\text { membuat laporan lembur, } \\
\text { laporan upah lembur dan } \\
\text { entri data }\end{array}$ \\
\hline
\end{tabular}

Deskripsi pendifinisian use case pada sistem informasi perintah kerja kerja lembur adalah sebagai berikut:

Tabel 2 Definisi Use Case

\begin{tabular}{|l|l|l|}
\hline No & \multicolumn{1}{|c|}{ Aktor } & \multicolumn{1}{|c|}{ Deskripsi } \\
\hline 1. & Validasi & $\begin{array}{l}\text { Merupakan proses } \\
\text { pengecekan hak akses } \\
\text { siapa yang berhak } \\
\text { mengakses ristem } \\
\text { informasi perinath kerja } \\
\text { lembur yang } \\
\text { disesuaikan dengan } \\
\text { tingkat otorisasinya. }\end{array}$ \\
\hline 2. & Login & $\begin{array}{l}\text { Merupakan proses } \\
\text { untuk melakukan login } \\
\text { oleh masing-masing } \\
\text { actor. }\end{array}$ \\
\hline 3. & Logout & $\begin{array}{l}\text { Merupakan proses } \\
\text { untuk melakukan }\end{array}$ \\
\hline
\end{tabular}




\begin{tabular}{|c|c|c|}
\hline No & Aktor & Deskripsi \\
\hline & & $\begin{array}{l}\text { logout oleh masing- } \\
\text { masing aktor. }\end{array}$ \\
\hline 4. & $\begin{array}{l}\text { Rencana } \\
\text { lembur }\end{array}$ & $\begin{array}{lr}\text { Merupakan roses } & \text { proses } \\
\text { perencaan atan } \\
\text { pekerjaan lembur yang } \\
\text { sifatnya terencana } \\
\text { maupun yang tidak } \\
\text { terencana. }\end{array}$ \\
\hline 5. & $\begin{array}{l}\text { Perintah } \\
\text { Kerja lembur }\end{array}$ & $\begin{array}{l}\text { Merupakan proses } \\
\text { perintah kerja lembur } \\
\text { yang disampaikan oleh } \\
\text { Manager. }\end{array}$ \\
\hline 6. & Draft SPKL & $\begin{array}{l}\text { Merupakan proses } \\
\text { pembuatan draft SPKL } \\
\text { yang dilakukan oleh } \\
\text { Staff atas perintah } \\
\text { lembur. }\end{array}$ \\
\hline 7. & SPKL & $\begin{array}{lr}\text { Merupakan } & \text { proses } \\
\text { pembuatan surat } & \text { oleh } \\
\text { Manager } & \text { yang } \\
\text { diberikan kepada } & \text { Staff. }\end{array}$ \\
\hline 8. & $\begin{array}{l}\text { Memeriksa } \\
\text { status login }\end{array}$ & $\begin{array}{lr}\text { Proses } & \text { memeriksa } \\
\text { apakah } & \text { pengguna } \\
\text { sistem } & \text { informasi } \\
\text { perintah lembur sudah } \\
\text { melakukan login atau } \\
\text { belum. }\end{array}$ \\
\hline 9. & $\begin{array}{l}\text { Mengelola } \\
\text { biodata }\end{array}$ & $\begin{array}{l}\text { Proses generalisasi } \\
\text { memasukan biodata, } \\
\text { mengubah biodata, } \\
\text { menghapus biodata, } \\
\text { mencari biodata dan } \\
\text { melihat biodata yang } \\
\text { ada di basis data oleh } \\
\text { Admin Lembur Pusat }\end{array}$ \\
\hline 10. & $\begin{array}{l}\text { Mengelola } \\
\text { Jabatan }\end{array}$ & $\begin{array}{lr}\text { Proses } & \text { generalisasi } \\
\text { memasukan } & \text { data } \\
\text { jabatan, mengubah } \\
\text { jabatan, menghapus } \\
\text { jabatan, } \\
\text { jabatan dan mencari } \\
\text { jabatan yang ada di } \\
\text { basis data oleh Admin } \\
\text { Lembur Pusat }\end{array}$ \\
\hline 11. & $\begin{array}{l}\text { Mengelola } \\
\text { jenjang }\end{array}$ & $\begin{array}{lr}\text { Proses generalisasi } \\
\text { memasukan data }\end{array}$ \\
\hline
\end{tabular}

\begin{tabular}{|c|c|c|}
\hline No & Aktor & Deskripsi \\
\hline & & $\begin{array}{lr}\text { jenjang, } & \text { mengubah } \\
\text { jenjang, menghapus } \\
\text { jenjang, } \\
\text { jenjang dan mencari } \\
\text { jenjang yang ada di } \\
\text { basis data oleh Admin } \\
\text { Lembur Pusat. }\end{array}$ \\
\hline 12. & $\begin{array}{l}\text { Mengelola } \\
\text { posisi }\end{array}$ & $\begin{array}{l}\text { Proses generalisasi } \\
\text { memasukan data posisi, } \\
\text { mengubah posisi, } \\
\text { menghapus posisi, } \\
\text { mencari posisi dan } \\
\text { melihat posisi yang ada } \\
\text { di basis data oleh } \\
\text { Admin Lembur Pusat. }\end{array}$ \\
\hline 13 & $\begin{array}{l}\text { Mengelola } \\
\text { hari libur }\end{array}$ & $\begin{array}{l}\text { Proses generalisasi } \\
\text { memasukan data hari } \\
\text { libur, mengubah hari } \\
\text { libur, menghapus hari } \\
\text { libur, mencari hari libur } \\
\text { dan melihat hari libur } \\
\text { yang ada di basis data } \\
\text { oleh Admin Lmbur } \\
\text { Pusat }\end{array}$ \\
\hline 14 & $\begin{array}{l}\text { Tarif upah } \\
\text { lembur }\end{array}$ & $\begin{array}{l}\text { Proses generalisasi } \\
\text { memasukan data tarif } \\
\text { upah lember, mengubah } \\
\text { tarif upah lember, } \\
\text { menghapus tarif upah } \\
\text { lember, mencari tarif } \\
\text { upah lember dan } \\
\text { melihat tarif upah } \\
\text { lember yang ada di } \\
\text { basis data oleh Admin } \\
\text { Pusat }\end{array}$ \\
\hline 15 & $\begin{array}{l}\text { Ubah } \\
\text { password }\end{array}$ & $\begin{array}{l}\text { Proses mengubah } \\
\text { password lama menjadi } \\
\text { password baru. }\end{array}$ \\
\hline 16 & Laporan & $\begin{array}{l}\text { Proses pembuatan } \\
\text { laporan per unit maupu } \\
\text { per pegawai. }\end{array}$ \\
\hline
\end{tabular}

\section{B. Activity Diagram Usulan Lembur}

Berikut adalah diagram aktivitas proses membuat usulan draft surat perintah kerja lembur 
dari staff ke manager seperti terlihat pada gambar dibawah ini:

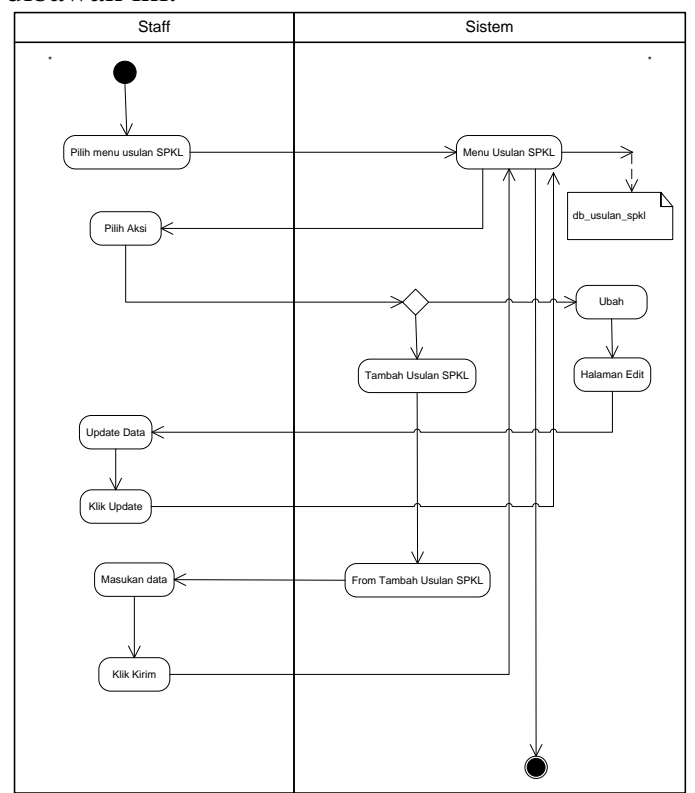

Gambar 5 Activty Diagram Usulan Lembur

\section{Activity Diagram Surat Perintah Kerja}

\section{Lembur}

Berikut adalah diagram aktivitas pembuatan Surat Perintah Kerja Lembur (SPKL) dari Manager ke Staff seperti terlihat pada gambar dibawah ini:

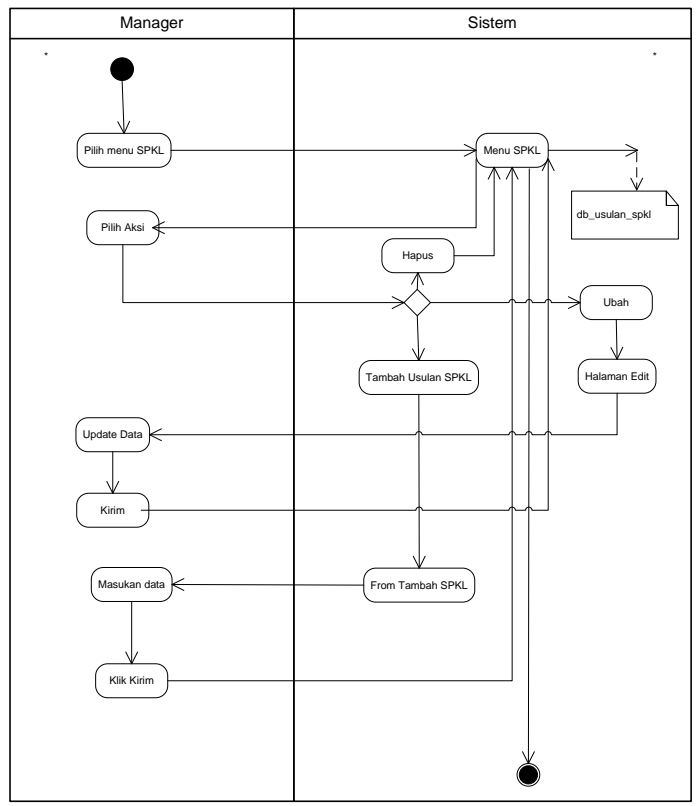

Gambar 6 Activity Diagram SPKL

\section{Activity Diagram Input Jam Lembur}

Berikut adalah diagram aktivitas input realisasi jam kerja lembur yang dilakukan oleh seorang HR Amin Unit, data jam lembur tersebut didapatkan dari hasil fingerprint dari staff yang melaksanakan kerja lembur seperti terlihat pada gambar dibawah ini:

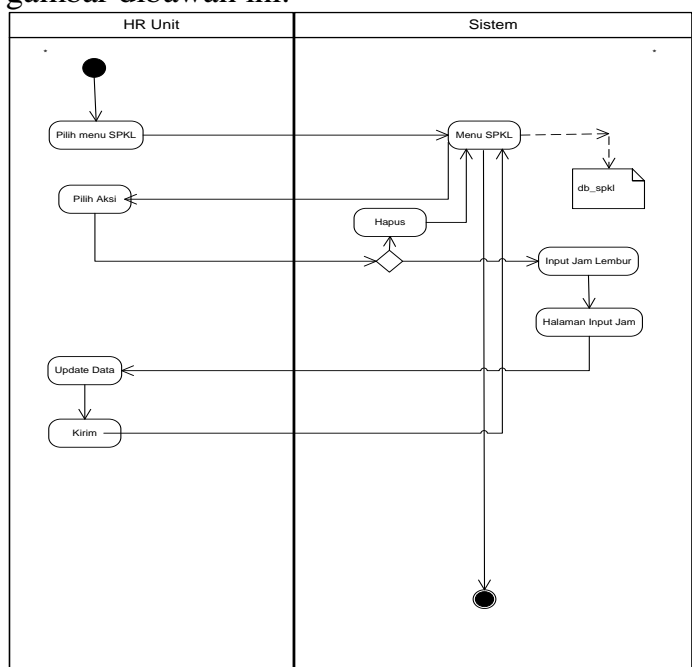

Gambar 7 Activity Diagram Input Jam Lembur

\section{E. Activity Diagram Laporan}

Berikut adalah diagram aktivitas pembuatan laporan lembur yang dilakukan oleh Admin Lembur Pusat seperti terlihat pada gambar dibawah ini:

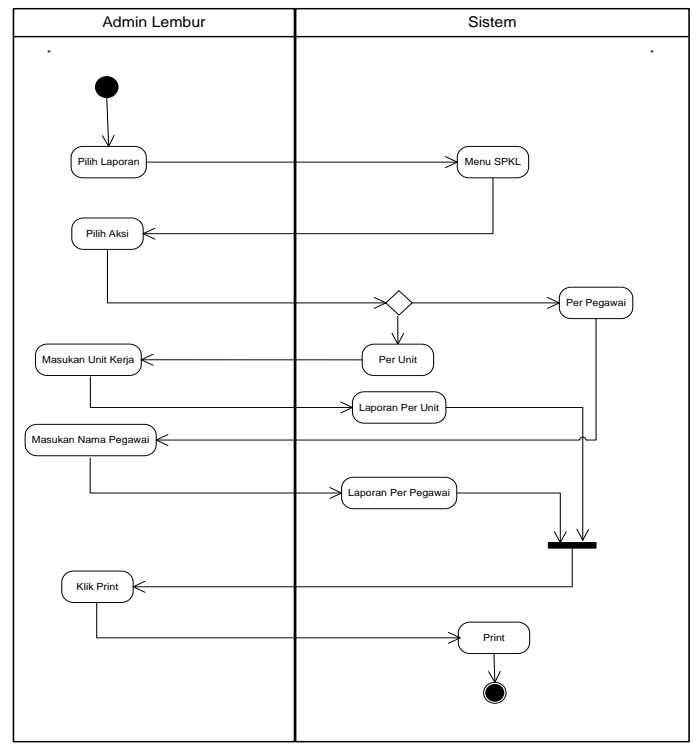

Gambar 8 Activity Diagram Laporan 


\section{Sequence Diagram Perintah Kerja Lembur}

Peroses pembuatan usulan perintah kerja lembur (SPKL) yang dilakukan oleh staff dapat dilihat pada diagram Sekuensial dibawah ini:

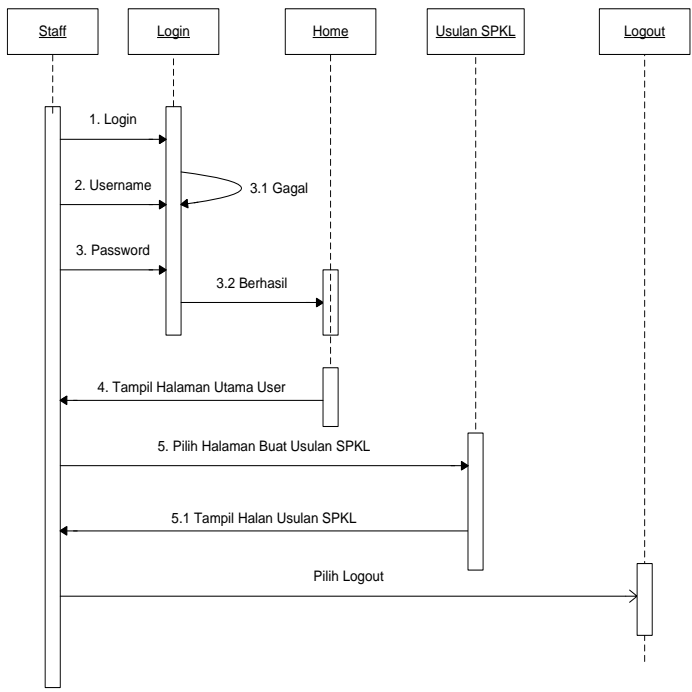

Gambar 9 Sequence Diagram (Staff)

Peroses pembuatan persetujuan dan pembuatan surat perintah kerja lembur (SPKL) yang dilakukan oleh manajer dapat dilihat pada diagram Sekuensial dibawah ini:

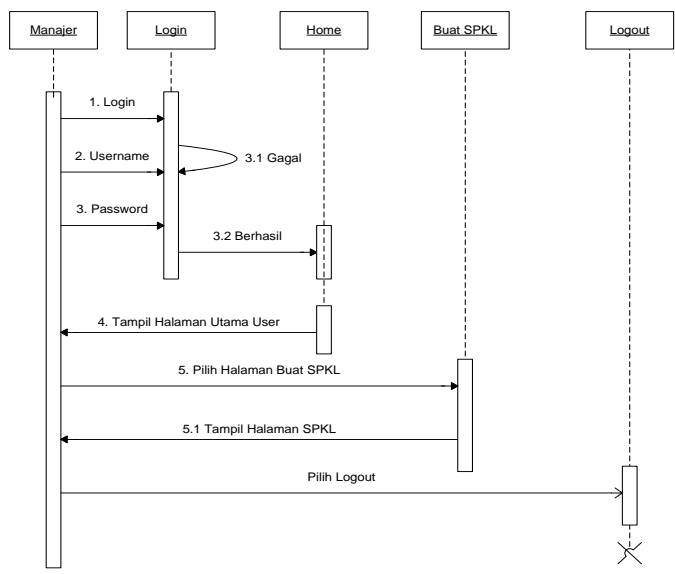

Gambar 10 Sequence Diagram (Manajer)

\section{E. Class Diagram Perintah Kerja Lembur}

Class diagram membantu menampilkan visuaisasi struktur class-class dalam suatu sistem dan merupakan tipe diagram yang paling banyak dipakai. Diagram memberikan gambaran detail mengenai class dalam model desain dari suatu sistem. Berikut class diagram dari sistem yang diajukan:

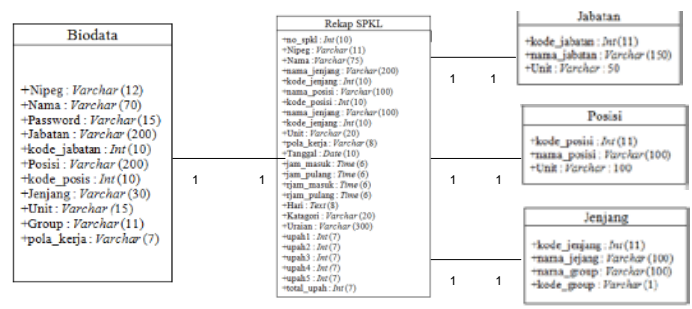

Gambar 11 Class Diagram

\section{F. Tampilan Program}

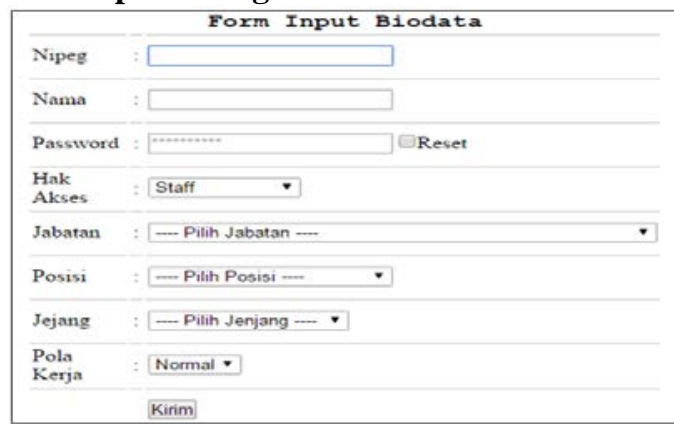

Gambar 12 Layar Form Input Biodata

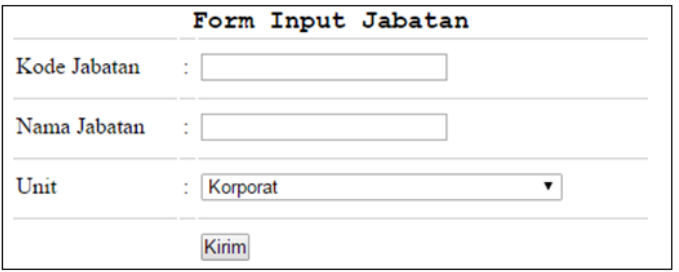

Gambar 13 Layar Form Input Jabatan

\begin{tabular}{|l|l|}
\hline & Form Input posisi \\
\hline Kode posisi & $:$ \\
\hline Nama posisi & $:$ \\
\hline Unit & $:$ Korporat \\
& Kirim \\
\hline
\end{tabular}

Gambar 14 Layar Form Input Posisi

\begin{tabular}{|lc|}
\hline Form Input Jenjang \\
\hline Node Jejang & $:$ \\
\hline Nama Jejang & $:$ \\
\hline Noma Group & Struktural $~$ \\
\hline Kode Group & S V \\
\hline
\end{tabular}

Gambar 15 Layar Form Input Jenjang 


\section{Ubah Password}

Masukkan password lama

Masukkan password baru

Masukkan kembali password baru

\section{Submit}

Gambar 16 Layar Ubah Password

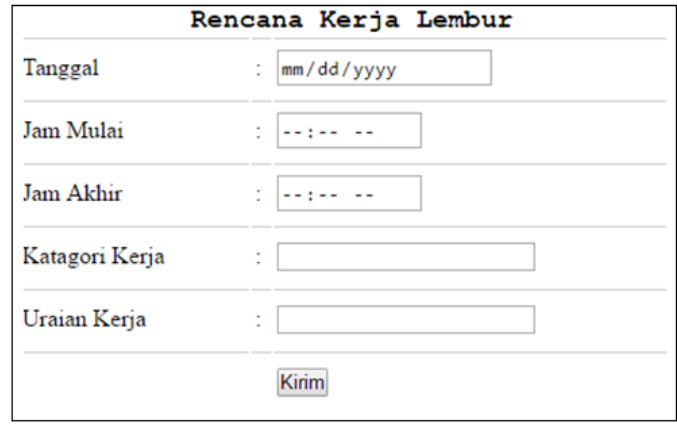

Gambar 17 Layar Input Rencana Kerja Lembur

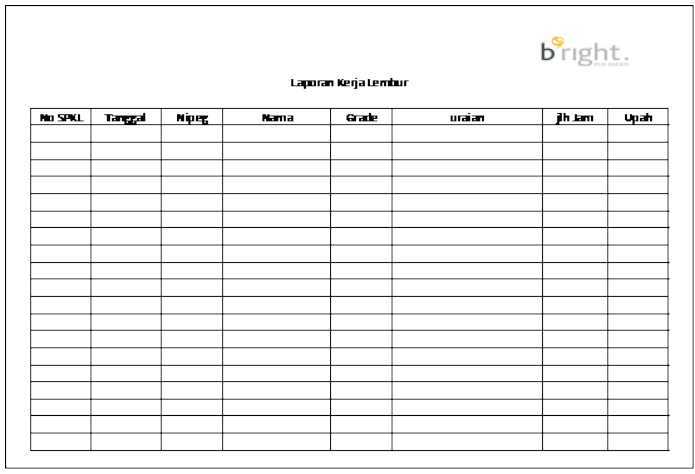

Gambar 18 Form Laporan Lembur

\section{G. Analisis Produktifitas}

\section{a). Segi Efisiensi}

Analisa produktifitas dari segi efesiensi pada sistem informasi perintah kerja lembur yang baru ini adalah dapat menghemat biaya pengunaan kertas karena tidak ada lagi form surat perintah lembur yang di cetak dan ditandatangani kemudian dikumpulkan, dibawa dan dilaporkan ke kantor pusat. Kemudian efensiensi juga akan terlihat segi waktu dimana tidak akan ada lagi keterlambatan penyampaian laporan pelaksanan kerja lembur.

\section{b). Segi Efektifitas}

Analisa produktifitas dari segi efektifitasnya pada sistem ini adalah SPKL akan mudah dibuat karena dilakukan melalui web sehingga SPKL yang dibuat mudah diawasi dan benar-benar untuk pekerjaan yang penting dan mendesak.

\section{Kesimpulan}

Dengan selesainya perancangan sistem informasi perintah kerja lembur ini, maka penulis dapat menarik kesimpulan sebagai berikut:

1 Sistem perintah kerja lembur yang dirancang berbasis web membuat produktifitas semakin meningkat karena Surat Perintah Kerja Lembur (SPKL) dan draft SPKL akan lebih mudah dibuat oleh Manager maupun staff.

2 Pembuatan laporan dan pencarian asip juga semakin cepat karena semua data lembur tersimpan dalam sebuah basis data.

\section{Ucapan Terima Kasih}

Penulis mengucapkan terima kasih kepada LPPM Universitas Putera Batam yang telah memberi dukungan financial terhadap penelitian ini.

\section{Daftar Pustaka}

[1] Al Fatta, Hanif. (2013). Analisis dan Perancangan Sistem Informasi. Yogyakarta: Andi.

[2] Ali, Hapzi dan Wangdra, Tonny. (2010). Sistem Informasi Bisnis "Si-Bis". Cetakan Pertama, Jakarta: Penerbit Baduose Media.

[3] Husda, Nur Elfi. (2012). Pengantar Teknologi Informasi. Cetakan Pertama. Penerbit Boduose. Jakarta.

[4] Hartono, Bambang. (2013). Sistem Informasi Manajemen Berbasis Komputer. Rineka Cipta, Jakarta.

[5] Jogiyanto, Hartono. (2010). Model Kesuksesan Sistem Teknologi Informasi. Yogyakarta: Andi Offset.

[6] Kadir, Abdul. (2014). Pengenalan Sistem Informasi. Edisi Revisi. Yogyakarta: Andi Offset.

[7] Rosa, A.S dan Salahuddin, M. (2011). Rekayasa Perangkat Lunak Terstruktur dan Berorientasi Objek. Informatika. Bandung. 
[8] Sutabri, Tata. (2012). Konsep Dasar Informasi. Yogyakarta: Andi Offset.

[9] Sutarman. (2012). Pengantar Teknologi Informasi. Jakarta: Bumi Aksara.

[10] Turban, Efraim dan Volonino, Linda. (2010). Information Technology for Management. Edisi Ketujuh.

[11] Yakub. (2012). Pengantar Sistem Informasi. Yogyakarta: Graha Ilmu.

[12] php.net, "PHP: History of PHP - Manual." [Online]. Available: http://php.net/manual/en/history.php.php. [Accessed: 01-Juni-2017].
[13] Saputra, Agus. (2012). PHP, HTML5, dan CSS3. Jakarta: Jasakom.

[14] Husni Al Amin, I., \& A, K. (2014). Aplikasi Customer Relationship Management (CRM) di Cv. Matahari Digital Printing Semarang. Dinamika Teknik, 8(2): 49-65.

[15] Januaris Kundre, A., Wisnubadhra, I., \& Suselo, T. (2013). Penerapan Customer Relationship Management dengan Dukungan Teknologi Informasi Pada Po. Chelsy. Seminar Nasional Teknologi Informasi dan Multimedia, 28: 7-11.

Milwandhari, S. (2011). Perancangan ECustomer Relationship Management Pada Perusahaan Bidang Jasa Perhotelan. SEMASSI, 1: 1-6. 